\title{
Inhibition of skin carcinogenesis by suppression of NF-KB dependent ITGAV and TIMP-1 expression in IL-32 $\gamma$ overexpressed condition
}

Yong Sun Lee ${ }^{1}$, Chung Hee Lee ${ }^{1,2}$, Jun Tae Bae ${ }^{1}$, Kyung Tak Nam', Dae Bong Moon ${ }^{1}$, Ok Kyung Hwang ${ }^{1}$, Jeong Soon Choi ${ }^{1}$, Tae Hoon Kim', Hyoung Ok Jun', Young Suk Jung ${ }^{1}$, Dae Yeon Hwang ${ }^{3}$, Sang-Bae Han ${ }^{1}$, Do Young Yoon ${ }^{4^{*}}$ and Jin Tae Hong ${ }^{1 *}$

\begin{abstract}
Background: Interleukin-32 (IL-32) has been associated with various diseases. Previous studies have shown that IL32 inhibited the development of several tumors. However, the role of IL-32 $\gamma$, an isotype of IL-32, in skin carcinogenesis remains unknown.

Methods: We compared 7,12-Dimethylbenz[a]anthracene/12-O-Tetradecanoylphorbol-13-acetate (DMBA/TPA)-induced

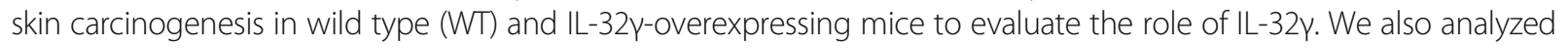
cancer stemness and NF-kB signaling in skin cancer cell lines with or without IL-32 $\gamma$ expression by western blotting, quantitative real-time PCR and immunohistochemistry analysis.
\end{abstract}

Results: Carcinogen-induced tumor incidence in IL-32 $\gamma$ mice was significantly reduced in comparison to that in WT mice. Infiltration of inflammatory cells and the expression levels of pro-inflammatory mediators were decreased in the skin tumor tissues of IL-32y mice compared with WT mice. Using a genome-wide association study analysis, we found that IL-32 was associated with integrin aV (ITGAV) and tissue inhibitor of metalloproteinase-1 (TIMP-1), which are critical factor for skin carcinogenesis. Reduced expression of ITGAV and TIMP-1 were identified in DMBATPA-induced skin tissues of IL-32 $\gamma$ mice compared to that in WT mice. NF-KB activity was also reduced in DMBA/TPA-induced skin tissues of IL-32 $\gamma$ mice. IL-32 $\gamma$ decreased cancer cell sphere formation and expression of stem cell markers, and increased chemotherapy-induced cancer cell death. IL-32 $\gamma$ also downregulated expression of ITGAV and TIMP-1, accompanied with the inhibition of NF-KB activity. In addition, IL-32y expression with NF-KB inhibitor treatment further reduced skin inflammation, epidermal hyperplasia, and cancer cell sphere formation and downregulated expression levels of ITGAV and TIMP-1.

Conclusions: These findings indicated that IL-32 $\gamma$ suppressed skin carcinogenesis through the inhibition of both stemness and the inflammatory tumor microenvironment by the downregulation of TIMP-1 and ITGAV via inactivation of NF-KB signaling.

Keywords: IL-32y, TIMP-1, ITGAV, NF-kB, Skin tumor development

\footnotetext{
* Correspondence: ydy4218@konkuk.ac.kr; jinthong@chungbuk.ac.kr

${ }^{4}$ Department of Bioscience and Biotechnology, Bio/Molecular Informatics Center, Konkuk University, Gwangjin-gu, Seoul 05029, Republic of Korea

${ }^{1}$ College of Pharmacy and Medical Research Center, Chungbuk National University, Osongsaengmyeong 1-ro, Osong-eup, Heungdeok-gu, Cheongju, Chungbuk 28160, Republic of Korea

Full list of author information is available at the end of the article
}

(c) The Author(s). 2018 Open Access This article is distributed under the terms of the Creative Commons Attribution 4.0 International License (http://creativecommons.org/licenses/by/4.0/), which permits unrestricted use, distribution, and reproduction in any medium, provided you give appropriate credit to the original author(s) and the source, provide a link to the Creative Commons license, and indicate if changes were made. The Creative Commons Public Domain Dedication waiver (http://creativecommons.org/publicdomain/zero/1.0/) applies to the data made available in this article, unless otherwise stated. 


\section{Introduction}

Interleukin-32 (IL-32), formerly known as natural killer cell transcript 4 , has six splice variants, namely IL-32 $\alpha$, $-32 \beta,-32 \gamma,-32 \delta,-32 \varepsilon$, and $-32 \zeta$, all of which demonstrate distinct functional differences [1, 2]. IL-32 consists of eight small exons and the second exon contains an ATG start codon. IL-32 $\gamma$ is the longest isoform. IL-32 $\alpha$ lacks two of the splicing variant regions found in IL-32 $\gamma$ (spliced between exons 3 and 4, and exons 7 and 8). IL-32 $\beta$ lacks the second exon, is spliced form between exons 3 and 4 of IL-32 $\gamma$. IL-32 $\delta$ lacks the second exon, which results in a shift in the ATG codon in the third exon. IL-32 $\varepsilon$ lacks exons 3 and 4 of IL-32 $\gamma$. IL-32 $\zeta$ lacks the second and third exons, and the ATG codon of IL-32 $\zeta$ is shifted in the fourth exons. It is well known that IL-32 plays significant pathophysiological roles in the development of several inflammatory diseases, such as arthritis, psoriasis, ulcerative colitis, Crohn's disease, and chronic obstructive pulmonary disease [3-6], since it alters the release of pro and anti-inflammatory cytokines such as tumor necrosis factor-alpha (TNF- $\alpha$ ), IL-1 $\beta$, IL-6, and IL-10 [5, 7, 8]. It has also been reported that IL-32 was critically associated with the development of several cancers $[9,10]$. Our recent studies have revealed that IL-32 $\alpha$ induced TNFR1-mediated cell death signaling to inhibit tumor development in carcinogen-induced colon tumors, while IL-32 $\beta$ and IL-32 $\gamma$ suppressed tumor growth through the inactivation of STAT3 and NF- $\mathrm{kB}$ signaling in xenograft and allograft animal [10-12]. In addition, IL-32 $\gamma$ and IL-32 $\theta$ inhibit stemness and epithelial-mesenchymal transition (EMT) in colon cancer [13]. It was also reported that IL-32 $\alpha$ induces cell apoptosis in human melanoma cells and inhibits EMT in pancreatic cancer cells [14, 15]. However, IL-32 $\alpha$ induces human melanoma migration, while IL-32 $\gamma$ increases gastric cancer migration and invasion $[16,17]$. However, the role of $\mathrm{IL}-32 \gamma$ in carcinogen-induced skin tumor growth and its mechanisms of action have not yet been reported.

Skin cancer is the most common cancer and its incidence is constantly increasing every year [18-20]. During the past few decades, the incidence of skin cancer has significantly increased in both the elderly and adolescents due to increases in chemical carcinogen exposure, ultraviolet exposure, tanning behavior of youth, and outdoor activities [19]. Several reports have demonstrated that chronic inflammation promoted epidermal cell transformation and malignant progression by enhancing the release of cytokines and chemokines and by infiltration of inflammatory cells $[21,22]$. Various inflammatory cytokines, including TNF- $\alpha$, IL-1, IL-6, IL-17, IL-21, and IL-23, promoted skin cancer development $[21,23]$. It was also noteworthy that inflammatory cytokines were positively related with cancer stemness.
IL-1 $\beta$ was shown to increase cancer sphere formation and stem cell marker expressions in colon cancer [24], while IL-6, IL-8, CCL2 and transforming growth factor- $\beta$ promoted breast cancer stemness [25]. Tumor-associated macrophages and $\mathrm{T}_{\mathrm{h}} 2$ cell-produced tumor necrosis factor (TNF)- $\alpha$ have been reported to promote cancer stem cell (CSC) plasticity [26]. CSCs, a rare population of tumor cells, are able to preserve tumor heterogeneity with their self-renewal capacity and clonal long-term repopulation potential [26]. Growing evidence has shown that CSCs play a critical role in tumor initiation in many cancer types, including skin cancer [27, 28]. The molecular mechanisms between tumor initiation and CSCs have been poorly characterized in chemical-induced skin carcinogenesis model. However, previous studies have revealed that skin stem cells or CSCs obtained from DMBA/ TPA-induced skin tumors contribute to initiate tumor development $[29,30]$. These results implicated that skin stem cells or CSCs may be important for tumor initiation in chemical-induced skin carcinogenesis model. Mice lacking Sox2, a core stem cell gene, showed delayed DMBA/TPA-induced skin tumor initiation and reduced tumor proliferation and stemness $[28,31]$. Expression of Nanog, another stem cell gene, promoted skin squamous cell carcinoma formation [32].

Integrin $\alpha v$ (ITGAV) heterodimers are known to promote or suppress cancer development in epithelial tissues. In the mouse skin, ITGAV cooperates with p53 to transiently promote initial skin cancer development, but ultimately results in decreased tumor growth [33]. Knockout of ITGAV in mice seemed to promote skin cancer development [34]. ITGAV knockdown and ITGAV antagonist treatment reduced cell migration, stemness, and EMT in prostate and bladder cancer [35-37]. It has also been reported that ITGAV positive colon cancer cells showed increased cancer stemness and chemoresistance [38]. TIMP-1 is a member of the family of matrix metalloproteinase inhibitors, which contains four members (TIMP-1, TIMP-2, TIMP-3, and TIMP-4) [39]. Growing evidence has demonstrated that TIMP-1 expression is related to skin cancer progression. TIMP-1-overexpressing melanoma cells showed elevated anchorage-independent growth in soft agar and increased tumorigenesis and lung metastasis in vivo [40]. The assembly of TIMP-1, CD63, and $\beta 1$-integrins at the cell surface of melanoma cells was involved in the acquisition of an anoikis-resistant phenotype [41]. Suppression of TIMP-1 secretion inhibited anchorage-independent growth of hepatic adenocarcinoma cells [42]. With the data analysis using a genome-wide association study (GWAS), we 
found that IL-32 was closely related to many cancers (Additional file 1: Figure S1), and further analysis showed that IL-32 was closely associated with several genes including ITGAV and TIMP-1 (Additional file 2: Figure S2A and S2B), which have been implicated in skin tumor development.

Nuclear transcription factor- $\kappa B$ (NF- $k B$ ) has been known to be an important factor in inflammation and cancer. In skin cancer, enhanced NF- $\mathrm{kB}$ activity leads to hyperproliferation and dysplasia of mouse epidermis. Epidermal keratinocyte-specific deletion of p65 protects DMBA/TPA-induced skin carcinogenesis [43]. NF- $\mathrm{KB}$ is activated by cytokines in tumors and tumor environments. Proinflammatory cytokines, IL- $1 \alpha$, IL- 6 and IL-8, activate the NF- $\kappa B$ signaling during tumor growth and metastasis. However, NF- $\mathrm{kB}$ activity was inhibited by IL-10, which is an important cytokine for anti-tumor immunity and inhibits melanoma growth and metastasis [44-46]. We have previously found that IL-32 $\gamma$ inhibited colon cancer development via inactivation of NF- $\mathrm{kB}$ signaling [10]. IL-32 $\beta$ also prevented tumor growth in colon and prostate cancers through the downregulation of NF- $\kappa B$ [47]. NF- $\kappa B$ activation induced tumor development by increasing TIMP-1 expression in KrasG12D lung cancer model [48]. In triple-negative breast cancer cells, NF- $\mathrm{B}$ activation promoted cell proliferation via TIMP-1 expression [49]. ITGAV induced colorectal cancer cell invasion mediated by activation of NF- $\mathrm{kB}$ signaling [50]. The NF- $\mathrm{KB}$ signal is closely related to cancer stemness. NF- $\kappa B$ activation led to induce expression of stem cell genes and CSC markers including CD133 and Sox2. It has also been reported that NF- $\mathrm{KB}$ controls the expression of cytokines, specifically IL-6, which contributed to the survival and self-renewal of CSCs [51].

Thus, in the present study, we investigated whether overexpression of IL-32 $\gamma$ could contribute to skin cancer development through changes in cancer stemness and the inflammatory tumor microenvironment via mediation of these network genes.

\section{Materials and methods}

\section{Animals}

Wild-type (WT, C57BL/6 J) mice were purchased from DBL (Eumsung, Korea). The IL-32 $\gamma$ mice were obtained descried in the previous study [10]. In brief, a 705-base pair fragment of the hIL-32 $\gamma$ gene was subcloned into the EcoRI sites of the pCAGGS expression vector. IL-32 $\gamma$ insertion was confirmed by amplification of genomic DNA isolated from the transgenic mice tails using Super Taq PLUS Pre-mix (RexGeneBioTech, Seoul, Korea) and the following specific primer set: sense, 5'-GAAGGTCCTCTCTGATGACA-3' and antisense, $5^{\prime}$-GAAGAGGGACAGCTATGACTG-3' (nt 2245-2225). Genomic DNA samples were extracted from transgenic mice tails and PCR analysis was performed for
IL-32 $\gamma$ gene expression. WT mice do not express IL-32 $\gamma$. IL-32 $\gamma$ transgenic mice have no overt phenotype compared with WT mice. IL-32 $\gamma$ mice were viable, fertile and have no tissue or organ abnormalities. The mice were housed and bred under specific pathogen free conditions at the Laboratory Animal Research Center of Chungbuk National University, Korea. The mice $(n=8)$ were maintained in a room with a constant temperature of $22 \pm 1{ }^{\circ} \mathrm{C}$, relative humidity of $55 \pm 10 \%$, and 12-h light/dark cycle, and fed standard rodent chow (Samyang Co., Gapyeong, Korea) and purified tap water ad libitum.

\section{Carcinogenesis protocols}

Eight-week old WT and IL-32 $\gamma$ mice were used. Skin carcinogenesis was performed as previously described [52]. The dorsal skin of the mice was shaved, and the exposed areas were treated with $25 \mu \mathrm{g}$ DMBA (Sigma, St. Louis, MO, USA) in $200 \mu \mathrm{L}$ of acetone per mouse. After 1 week, $5 \mu \mathrm{g}$ TPA (Sigma, St. Louis, MO, USA) in $200 \mu \mathrm{L}$ of acetone was applied per mouse thrice a week. Mice were evaluated weekly for papilloma development. Mice were euthanized after a 25-week TPA treatment. At the time of sacrifice, the skin was fixed in $4 \%$ formalin solution. After fixation, the skin was used for surface tumor number and diameter measurements and then embedded in paraffin. Tumor counts were averaged and statistically analyzed. Tumor diameters were measured using Fisherbrand Traceable digital calipers (Fisher Scientific, Asheville, NC, USA). Then, skin tissues were embedded in paraffin. To induce skin inflammation, single TPA was applied on the shaved mice. The shaved mice were treated with or without $0.1 \mu \mathrm{mol}$ Bay 11-7082 in $200 \mu \mathrm{L}$ of acetone per mouse. After $1 \mathrm{~h}$, mice were treated with $10 \mu \mathrm{g} \mathrm{TPA}$ in $200 \mu \mathrm{L}$ of acetone per mouse. Mice were sacrificed after $24 \mathrm{~h}$.

\section{Cell culture}

A431 and SK-MEL-28 human skin cancer cells were obtained from the Korean Cell Line Bank (Seoul, Korea). A431 cells were grown in RPMI1640 supplemented with $10 \%$ fetal bovine serum, $100 \mathrm{U} / \mathrm{mL}$ penicillin, and $100 \mu \mathrm{g} / \mathrm{mL}$ streptomycin. SK-Mel-28 cells were grown in MEM supplemented with $10 \%$ fetal bovine serum, $1 \mathrm{mM}$ sodium pyruvate, $1 \times$ MEM non-essential amino acid, $100 \mathrm{U} / \mathrm{mL}$ penicillin, and $100 \mu \mathrm{g} / \mathrm{mL}$ streptomycin. Cells were cultured at $37{ }^{\circ} \mathrm{C}$ in $5 \% \mathrm{CO}_{2}$ humidified air.

\section{Sphere formation assay}

A431 and SK-Mel-28 cells were cultured in stem cell media consisting of DMEM/F12 basal media supplemented with $\mathrm{N} 2$ and B27 supplements (Invitrogen), $20 \mathrm{ng} / \mathrm{mL}$ human recombinant epidermal growth factor (EGF; PeproTech Inc., Rocky Hill, NJ) and $20 \mathrm{ng} / \mathrm{mL}$ 
basic fibroblastic growth factor (bFGF; PeproTech Inc., Rocky Hill, NJ). Before assay, 2-hydroxyethyl methacrylate (poly-HEMA) solution was prepared by mixing $1.2 \mathrm{~g}$ poly-HEMA in $100 \mathrm{ml} \mathrm{95 \%} \mathrm{ethanol} \mathrm{and} \mathrm{heating} \mathrm{at} 65^{\circ}$ C. Plates were coated by poly-HEMA solution in a sterile hood for 8 h. Poly-HEMA coated plates were sterilized by UV irradiation for $15 \mathrm{~min}$. For the sphere formation assay, cells were plated at a density of $1 \times 10^{4}$ cells/well in poly-HEMA-coated 12-well plates. After 10 days, number of spheres were counted.

\section{Transfection}

Skin cancer cells were transiently transfected with pcDNA3.1(+)-6xMyc-IL-32 $\gamma$ vector or control vector using the Lipofectamine 3000 transfection reagent in OPTI-MEM, according to the manufacturer's specification (Invitrogen, Waltham, MA, USA). For stable cell lines, transfected cells were cultured in growth medium containing $600 \mu \mathrm{g} / \mathrm{ml} \mathrm{G418} \mathrm{(Geneticin}{ }^{\mathrm{mm}}$; Gibco, Grand Island, NY, USA) for 2 weeks. G418-resistant colonies were selected and expanded. For siRNA transfection, negative control (NC), ITGAV and TIMP-1 siRNA were purchased from Santa Cruz Bio (Dallas, TX, USA).

\section{Chemotherapy resistance assay}

Cells were seeded in 96-well plates at $2.5 \times 10^{3}$ cells/well. After $24 \mathrm{~h}$, the cells were treated with 5 -fluorouracil (5-FU; $100 \mu \mathrm{g} / \mathrm{ml}$ ). The cells were incubated for $24 \mathrm{~h}$. Then, cell viability was measured by performing a thiazolyl blue tetrazolium bromide (MTT) assay. For MTT assay, $10 \% \mathrm{vol} / \mathrm{vol}$ of $5 \mathrm{mg} / \mathrm{ml} \mathrm{MTT} \mathrm{(Sigma,} \mathrm{St.} \mathrm{Louis,}$ MO, USA) diluted in PBS was added to cancer cell cultures. After $2 \mathrm{~h}$ of incubation, the medium was aspirated, and DMSO was added. Absorbance was measured at $570 \mathrm{~nm}$. The data were normalized to their respective controls and are presented as a bar graph.

\section{Quantitative real-time PCR}

Total RNA of skin tissues from WT mice and IL-32 $\gamma$ mice was extracted by Ribo ${ }^{\mathrm{EX}}$ RNA Extraction Kit (Gene All biotechnology, Seoul, Korea) and cDNA was synthesized using High Capacity RNA-to-cDNA kit (Applied Biosystems, Foster City, CA, USA). Quantitative real-time PCR was performed using QuantiNova SYBR Green RT-PCR kit (Qiagen, Hilden, Germany) with specific primers in a StepOnePlus ${ }^{\text {Th }}$ Real-Time PCR System (Applied Biosystems, Foster City, CA, USA) (Additional file 3: Table S1). Thermocycling conditions consisted of an initial denaturation of $20 \mathrm{~s}$ at $95.0{ }^{\circ} \mathrm{C}$, followed by 40 cycles of $95.0{ }^{\circ} \mathrm{C}$ for $30 \mathrm{~s}$ and $60.0{ }^{\circ} \mathrm{C}$ for $30 \mathrm{~s}$. The values obtained for the target gene expression were normalized to GAPDH or $\beta$-actin and quantified relative to the expression in control samples.

\section{Immunohistochemistry}

Human skin tumor tissue microarrays were purchased from US Biomax (SK801b; Rockville, MD, USA). Paraffin-embedded human and mouse tumor tissue sections were blocked for 60 min with $2 \%$ normal horse or goat serum diluted in PBS. The sections were then blotted and incubated with specific primary antibodies in blocking serum for overnight at $4{ }^{\circ} \mathrm{C}$. The next day, the slides were washed three times for $5 \mathrm{~min}$ each in PBS and incubated in biotinylated anti-mouse, rabbit, rat or goat antibody for $1 \mathrm{~h}$. The slides were washed in PBS, followed by formation of the avidin-biotin-peroxidase complex (ABC, Vector Laboratories, Inc., Burlingame, CA, USA). The slides were washed, and the peroxidase reaction developed with diaminobenzidine and peroxide, then counterstained with hematoxylin, mounted in Cytoseal XYL (Thermo Fisher Scientific, Waltham, MA, USA $)$, and evaluated using a light microscope $(\times 200$, Olympus, Tokyo, Japan). Specific primary antibodies were purchased from Santa Cruz Bio (PCNA, F4/80 and p50; Dallas, TX, USA), eBioscience (Ly6G and CD11b; Thermo Fisher Scientific, Waltham, MA, USA), Abnova (CD133; Taipei, Taiwan), Novus Biologicals (TIMP-1; Littleton, CO, USA) and Abcam (IL-32, CD44, ITGAV and p65; Cambridge, MA, USA).

\section{Prostaglandin E2 quantification}

Serum level of mouse prostaglandin E2 were measured by enzyme-linked immunosorbent assay (ELISA) kits provided by R\&D systems (Minneapolis, MN, USA) according to the manufacturer's protocol.

\section{Western blot analysis}

Skin tissues from WT mice and IL-32y mice were lysed by Pro-prep protein extraction buffer (iNtRON, Sungnam, Korea) and the total protein concentration was determined using the Bradford reagent (Bio-Rad, Hercules, CA, USA). Nuclear extraction was performed using nuclear extraction kit (Abcam, Cambridge, MA, USA). The membranes were immunoblotted with specific primary antibodies. The intensity of the bands was measured using the Fusion FX 7 image acquisition system (Vilber Lourmat, Eberhardzell, Germany). Specific primary antibodies were purchased from Santa Cruz Bio $(\mathrm{p}-\mathrm{IKK} \alpha / \beta, \mathrm{IKK} \alpha / \beta, \mathrm{p}-J \mathrm{NK}, \mathrm{JNK}, \mathrm{p}-\mathrm{ERK}, \mathrm{p}-\mathrm{p} 38, \mathrm{p} 38$, p-STAT3, STAT3, p50, Histone H1, Cyclin D1, CDK4, Bax, Bcl-2, MMP-2, MMP-9 and $\beta$-actin; Dallas, TX, USA), Cell Signaling Technology (Myc-tag and ERK; Trask Lane, Danvers, MA, USA), Abnova (CD133; Taipei, Taiwan), Novus Biologicals (TIMP-1, iNOS and COX-2; Littleton, CO, USA) and Abcam (CD44, ITGAV, S100A8 and p65; Cambridge, MA, USA). $\beta$-actin and histone $\mathrm{H} 1$ was used as a loading control. 


\section{Electrophoretic mobility shift analysis}

DNA binding activity of NF- $\mathrm{kB}$ was determined using an electrophoretic mobility shift assay (EMSA). Gel-shift assays were performed according to the manufacturer's recommendations (Promega, Madison, WI).

\section{Gene and gene-disease network analyses}

The gene network of IL-32 was analyzed using the web-based analysis tool GeneMANIA (www.genemania.org) based on the publicly available biological datasets (gene-gene interactions based on attributions: co-expression, co-localization, genetic interactions, pathway, physical interactions, predicted interactions and shared protein domains). The gene network is automatically analyzed by gene-ontology base weighting methods. The gene-disease network of IL-32 was analyzed using the DiseaseConnect (http://disease-connect.org) resource. This web server analyzed gene-disease network based on various sources, such as DEG, GWAS, OMIM, GeneRIF and GeneWays. The strength of the connections between an input gene and diseases is quantified as the $p$-value of a hypergeometric enrichment test in the number of shared genes.

\section{Data analysis}

The data were analyzed using the GraphPad Prism software ver 4.03 (San Diego, CA, USA). Data are presented as mean \pm S.E.M. The differences in all data were assessed by one-way analysis of variance (ANOVA). When the $P$ value in the student's $t$-test indicated statistical significance, the differences were assessed by the Dunnett's test. A value of $p<0.05$ was considered to be statistically significant.

\section{Results}

\section{IL-32 $\gamma$ inhibits skin tumor development}

First, we investigated the effect of IL-32 $\gamma$ on skin tumor development. Skin carcinogenesis was initiated by a single treatment with 7,12-dimethylbenz[a]anthracene (DMBA),

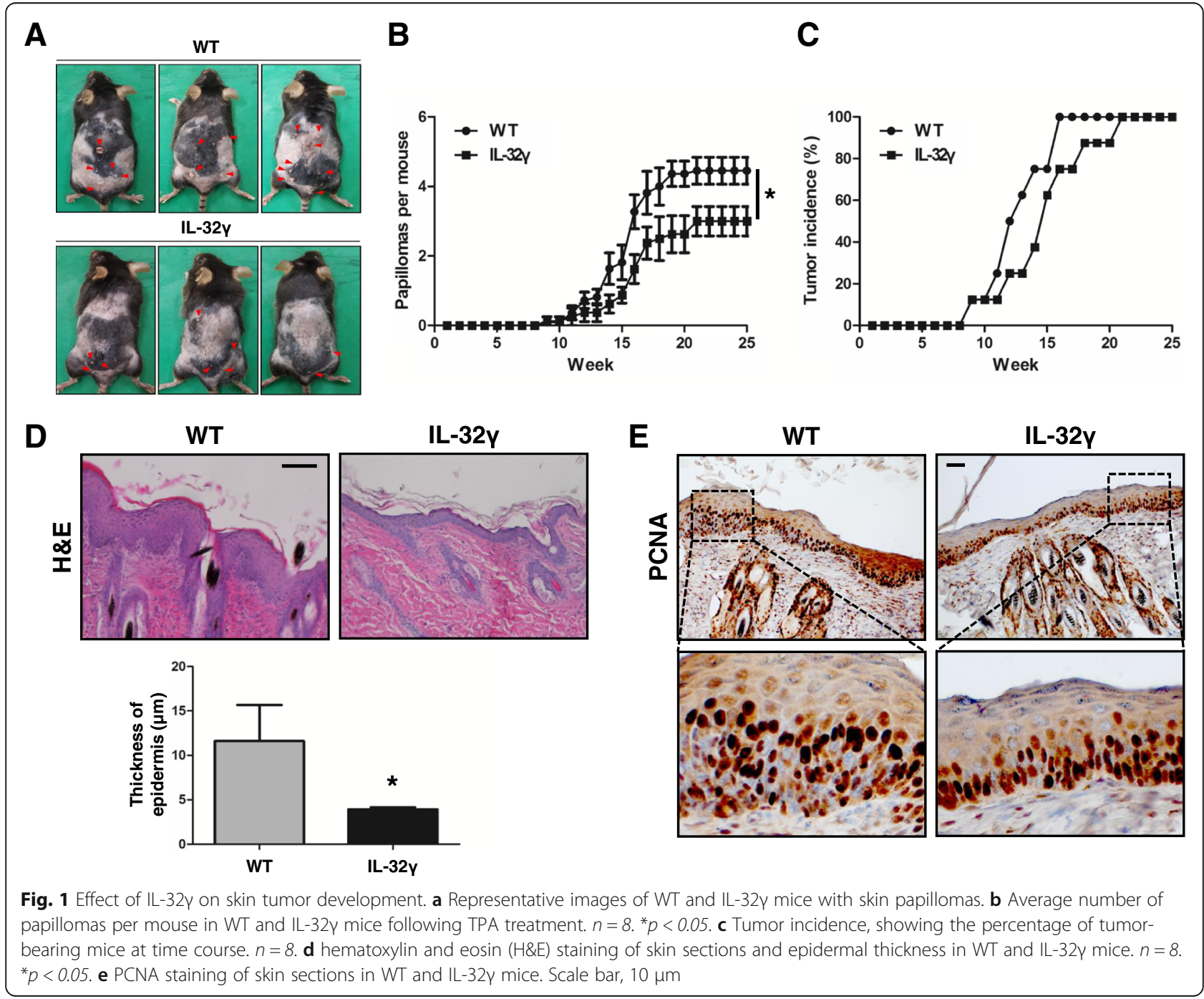


and then promoted by 12-O-tetradecanoylphorbol-13-acetate (TPA) treatments for 25 weeks. IL-32y mice showed a significantly reduced number of skin papillomas (Fig. 1a). The number of papillomas was $2.75 \pm 1.03$ per IL-32 $\gamma$ mouse compared to $5.125 \pm 0.99$ per WT control (Fig. 1b). Tumor development was delayed in IL-32 $\gamma$ mice compared to in WT mice (Fig. 1c). Histological analysis of skin sections from IL-32 $\gamma$ mice showed reduced epidermal thickening and hyperplasia compared to WT mice (Fig. 1d). The number of PCNA-positive cells was smaller in IL-32 $\gamma$ mice than in the WT controls (Fig. 1e). Additional western blot analysis showed that the expression levels of proliferation (PCNA, CDK4, and cyclin D1), metastasis (MMP-2 and MMP-9) and inflammation (COX-2 and iNOS) markers were decreased in skin tissues of IL-32 $\gamma$ mice compared to those of WT mice (Additional file 4: Figure S3). It has been previously demonstrated that DMBA/TPA induced skin carcinogenesis through MAPK and STAT3 signaling [53, 54]. We identified the activation of JNK, ERK, p38, and
STAT3 in skin tissues from WT and IL-32 $\gamma$ mice. Phosphorylation of JNK, p38, and STAT3 was reduced, but the phosphorylation status of ERK did not change in skin tissues from IL-32 $\gamma$ mice compared to that from WT mice (Additional file 4: Figure S3).

\section{IL-32 $\gamma$ inhibits local skin inflammation and affected inflammatory cell number}

Many studies revealed that local inflammation and infiltration of immune cells was correlated with skin cancer development. To investigate whether the reduced skin inflammation and infiltration of immune cells into skin were associated with IL-32 $\gamma$ mice with reduced skin carcinogenesis, we investigated the level of Th1/M1 pro-inflammatory cytokines, Th2/M2 anti-inflammatory cytokines and chemokines in DMBA/TPA-induced skin tissues. We found that mRNA levels of Th1/M1 pro-inflammatory mediators, such as IL-1 $\beta$, IL- 6 and TNF- $\alpha$, were decreased in IL-32 $\gamma$ mice compared to that in WT mice (Fig. 2a). However, Th2/M2

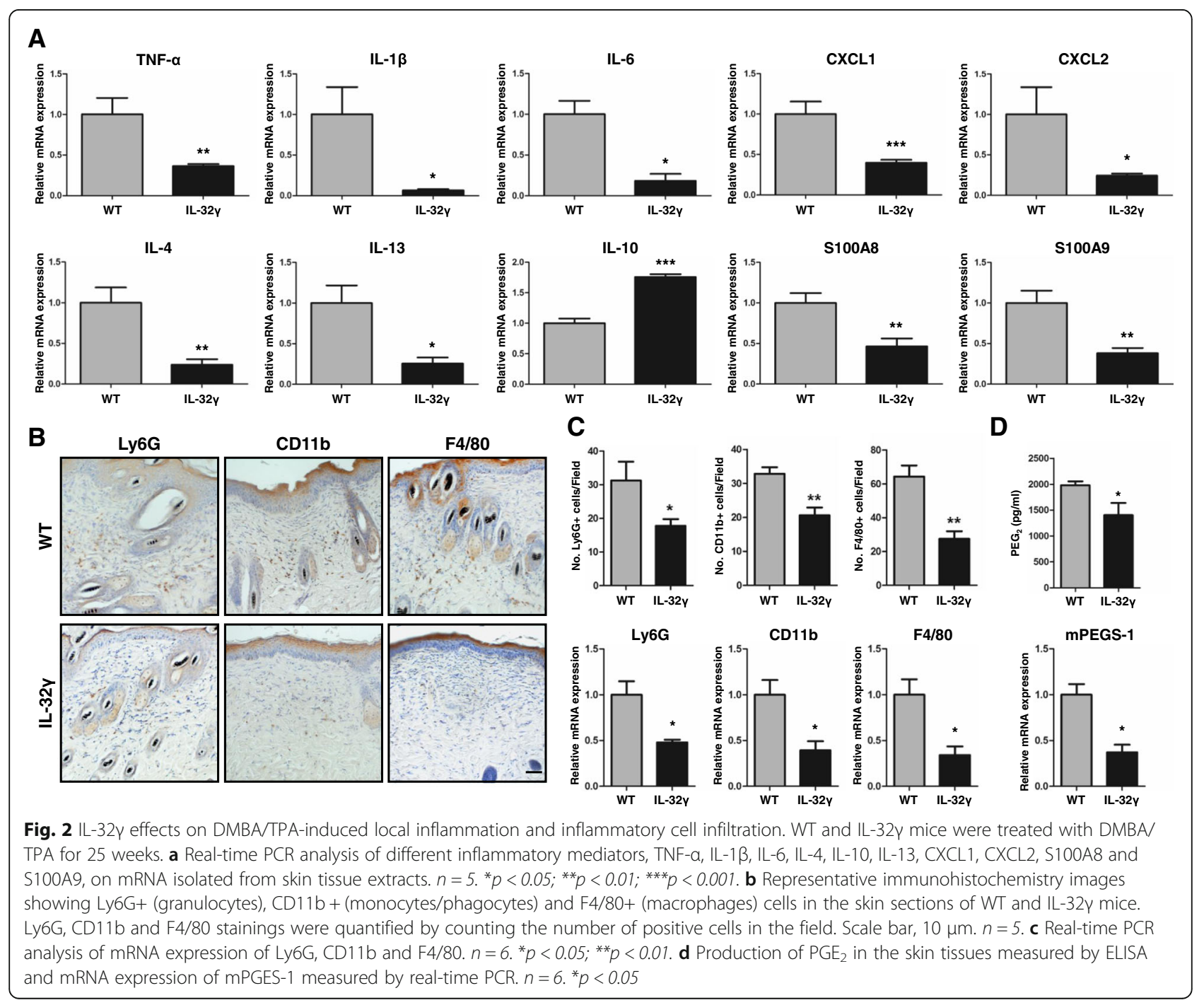


anti-inflammatory cytokines, including IL-4 and IL-13, were reduced, but IL-10 was increased in IL-32 $\gamma$ mice compared to that in WT mice (Fig. 2a). S100A8, S100A9, CXCL1 and CXCL2, chemoattractant chemokines which are important factors for recruiting inflammatory cells, were also decreased in the skin tissue from IL-32 $\gamma$ mice compared to that from WT mice (Fig. 2a). Moreover, we found a reduced recruitment of Ly6G+ granulocytes, CD11b + monocytes/phagocytes and F4/80+ macrophages in the skin tissues of IL-32 $\gamma$ mice compared to that in WT mice (Fig. 2b). In line with these findings, IL-32 $\gamma$ mice had lower mRNA expression levels of Ly6G, CD11b, and F4/80 compared to WT mice (Fig. 2c). In addition, the level of the inflammatory mediator prostaglandin $\mathrm{E}_{2}\left(\mathrm{PGE}_{2}\right)$, and mRNA expression of $\mathrm{PGE}_{2}$ synthase mPGES-1 were also significantly reduced in skin tissues from IL-32 $\gamma$ mice compared to those from WT mice (Fig. 2d).

\section{IL-32 $\gamma$ suppresses skin cancer stemness}

Next, we investigated whether IL-32 $\gamma$ inhibited skin cancer cell growth. Unexpectedly, no significant differences were observed for the in vitro proliferation rates between the control and IL-32 $\gamma$-overexpressing cells in HaCaT, A431 and SK-Mel-28 cell lines (Additional file 5: Figure S4). During cancer progression, CSCs are involved in tumor initiation and progression [55]. CSCs, known as tumor-initiating cells, have the potential for self-renewal, clonal tumor initiation, and clonal long-term repopulation. Thus, CSCs can initiate and sustain aggressive tumor growth [26]. We questioned whether IL-32 $\gamma$ inhibited cancer stemness, and thus IL-32 $\gamma$ reduced tumor development. First, we investigated whether expression of CSC markers was inhibited in DMBA/TPA-induced skin tissues of IL-32 $\gamma$ mice. As expected, the expression levels of CD44 and CD133 were much lower in the skin tissues of IL-32 $\gamma$ mice compared to WT mice as evaluated by western blotting and immunohistochemistry (Fig. 3a and b). It was also found that the number and size of spheroid bodies was reduced in IL-32 $\gamma$-overexpressing A431 and SK-MEL-28 cells compared with those in the control A431 and SK-Mel-28 cells (Fig. 3c). In accordance with reduced stemness, the expression of CSC markers, CD44 and CD133, were decreased in IL-32 $\gamma$ overexpressing skin cancer cells (Fig. 3d). In addition, the mRNA expression of Sox 2 was also reduced in IL-32 $\gamma$ overexpressing cells (Fig. 3e). CSCs may play a critical role in cancer chemoresistance by enhanced aldehyde dehydrogenase (ALDH) activity and DNA damage response [56]. Moreover, previous studies have revealed that CD44- or CD133-positive CSCs were highly resistant to chemotherapy [57]. We examined whether IL-32 $\gamma$ affected cancer chemotherapy resistance. A cell viability assay using 5-fluorouracil (5-FU) showed that IL-32 $\gamma$ induced the effect of 5 -FU treatments by increasing skin cancer cell death in A431 and SK-Mel-28 cells (Fig. 3f). Our findings suggest that IL-32y inhibited CSC properties in skin cancer cells.

\section{Expression levels of ITGAV and TIMP-1 are associated with the inhibition of IL-32 $\boldsymbol{\gamma}$-induced cancer stemness} Using the GWAS analysis, we found that IL-32 was associated with ITGAV and TIMP-1. Previous studies have shown that the inhibition of ITGAV expression decreased cancer stemness, migration and EMT in bladder carcinoma cells [36]. Elevated TIMP-1 levels contributed to increase colony formation in soft agar [40]. To assess the relationship between IL-32 $\gamma$ and these genes, we evaluated the expression levels of ITGAV and TIMP-1 in IL-32 $\gamma$-expressing DMBA/ TPA-induced skin tissues and skin CSCs. Using western blot analysis, ITGAV and TIMP-1 expression were found to be decreased in DMBA/TPA-induced skin tissues from IL-32 $\gamma$ mice compared to tissues from WT mice (Fig. 4a). Moreover, immunohistochemical analysis showed that the expression levels of these genes were reduced in DMBA/TPA-induced skin tissues of IL-32 $\gamma$ mice (Fig. 4b). We next investigated the expression levels of ITGAV and TIMP-1 in skin CSCs. The expression levels of ITGAV and TIMP-1 were decreased in IL-32 $\gamma$-overexpressing A431 and SK-Mel-28 CSCs compared to that in control CSCs (Fig. 4c). We further investigated whether ITGAV or TIMP-1 was associated with cancer stemness. We showed that knockdown of ITGAV and TIMP-1 reduced sphere formation in A431 and SK-Mel-28 cells (Fig. 4d). The expression levels of CD44 and CD133 were decreased by knockdown of ITGAV and TIMP-1 in skin cancer cells compared to control cells (Fig. 4e). Also, knockdown of ITGAV downregulated TIMP-1 expression, but not vice versa (Fig. 4e). Additionally, mRNA expression of Sox2 was downregulated in ITGAV and TIMP-1 knockdown A431 and SK-Mel-28 cells (Fig. 4f). These results indicated that IL-32 $\gamma$ suppressed cancer stemness through inhibition of ITGAV-mediated TIMP-1 expression.

\section{IL-32 $\gamma$ decreases NF-кB activity in tumor tissues and skin cancer stem cells}

NF- $\mathrm{kB}$ signaling has a key role in inflammation- and tumor-promoting functions in various tissues [58]. Previous studies revealed that increased expression of p50 was observed during mouse skin carcinogenesis and epidermal knockout of p65 abolished DMBA/TPA-induced skin carcinogenesis $[43,59]$. Moreover, NF- $\mathrm{KB}$ was closely associated with cancer stemness [51]. To determine whether IL-32 $\gamma$ inhibited the activation of NF-kB in DMBA/ TPA-induced skin tissues and CSCs, we conducted western blot and immunohistochemical analyses to examine the translocation of p50 and p65 into the nucleus and 


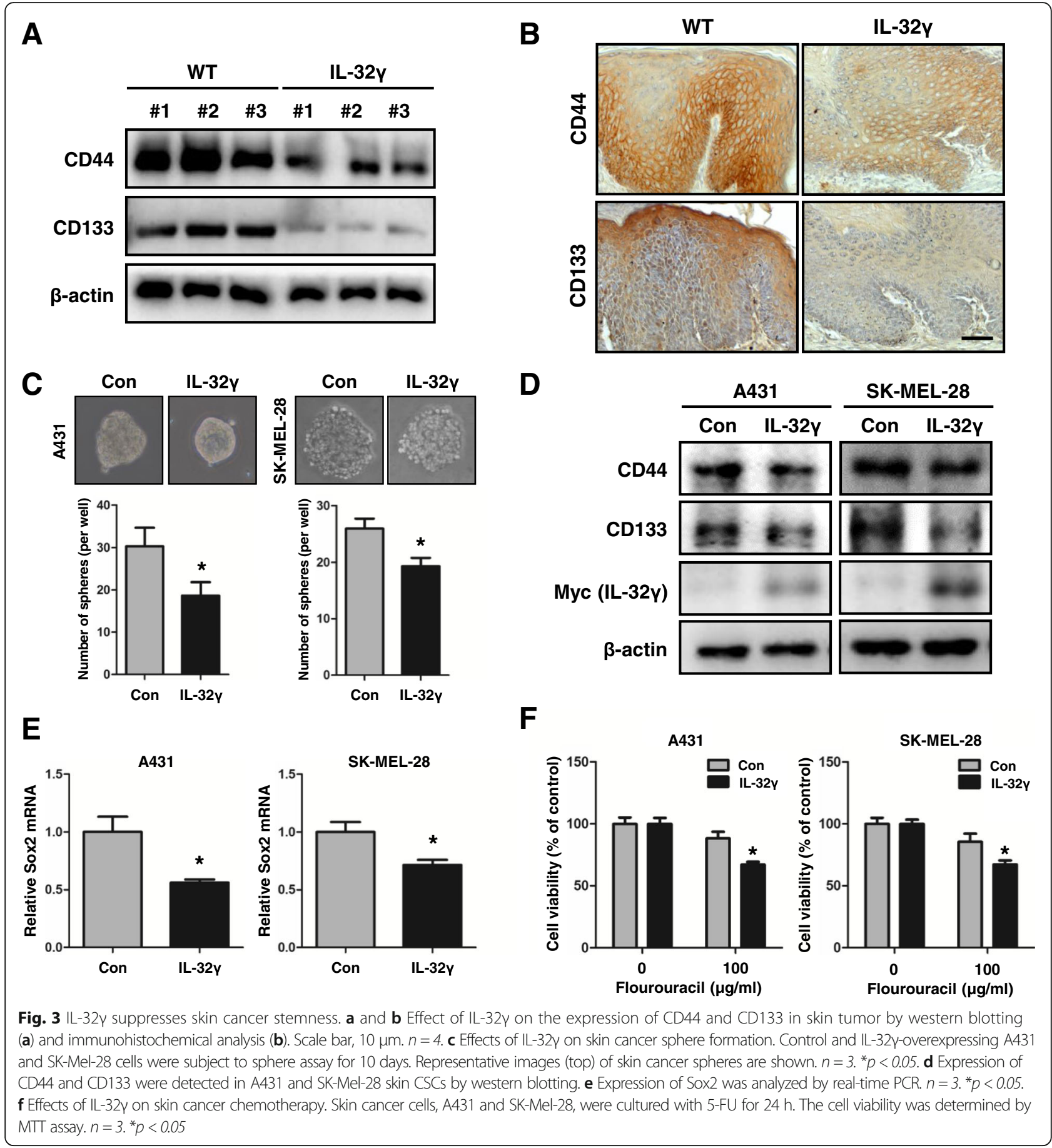

phosphorylation of IKK $\alpha / \beta$. The translocation of p50 and p65 into the nucleus and phosphorylation of IKK $\alpha / \beta$ were significantly decreased in the DMBA/TPA-induced skin tissues and IL-32 $\gamma$-overexpressing skin CSCs (Fig. 5a and b). Immunohistochemical analysis of p50 and p65 confirmed that the nuclear staining intensities for $\mathrm{p} 50$ and p65 were decreased in the DMBA/TPA-induced skin tissues of IL-32 $\gamma$ mice compared to controls (Fig. 5c). The DNA-binding activity of NF- $\mathrm{BB}$ was lower in
IL-32y-overexpressing skin CSCs compared to controls (Fig. 5d). These data implicated that IL-32y inactivated NF- $\mathrm{kB}$ in skin tissues and skin CSCs, which were associated with the inhibition of skin carcinogenesis.

Inhibition of NF-кB activity suppresses cancer stemness and skin inflammation

We showed that NF-kB signaling was inactivated in skin tissues and skin CSCs. Thus, we further examined the 


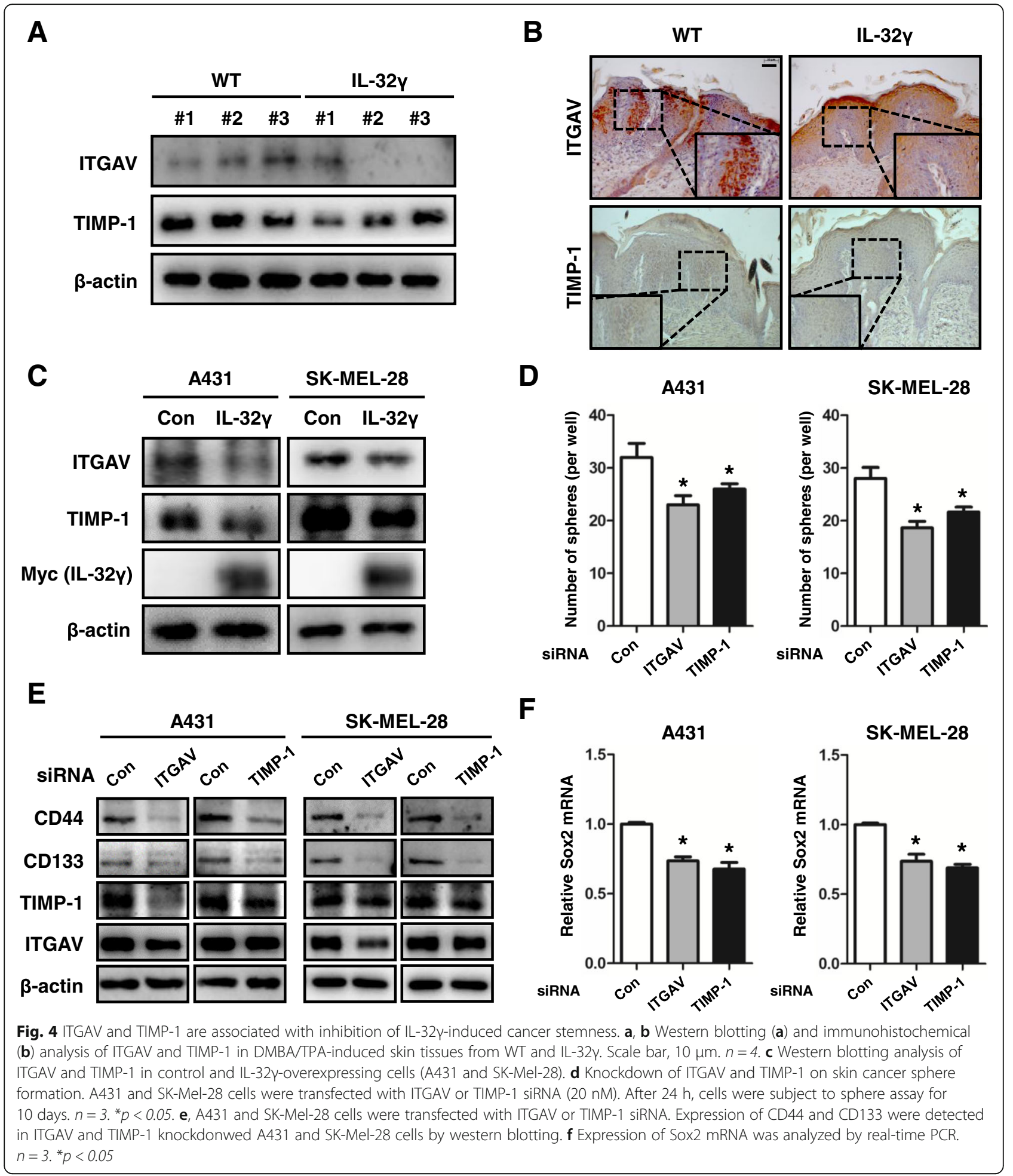

role of NF- $\kappa B$ in cancer stemness and skin inflammation after treatment of the NF- $\kappa B$ inhibitor, BAY 11-7082 (BAY). IL-32 $\gamma$ mice treated with BAY showed substantially reduced TPA-induced epidermal thickness (Fig. 6a). The expression levels of ITGAV, TIMP-1, and inflammation marker S100A8 were more decreased in TPA-induced skin tissues from BAY-treated IL-32 $\gamma$ mice (Fig. 6b). Moreover, local inflammation and inflammatory cell infiltration were more reduced in BAY-treated TPA-induced skin tissues from IL-32 $\gamma$ mice compared with that from controls (Additional file 6: Figure S5A and B). The NF-kB inhibitor treatment demonstrated a significant inhibitory 


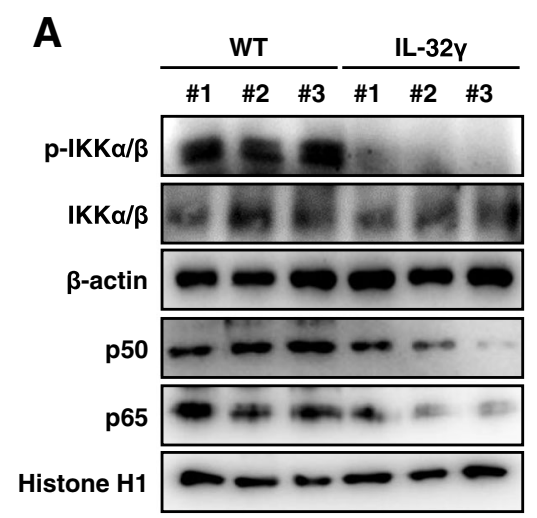

B

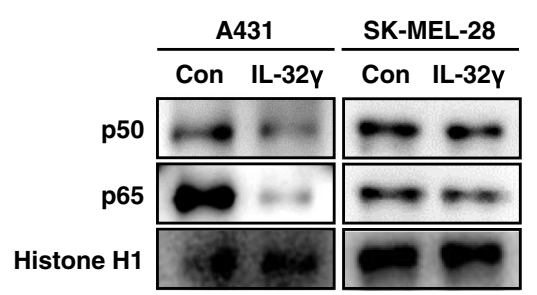

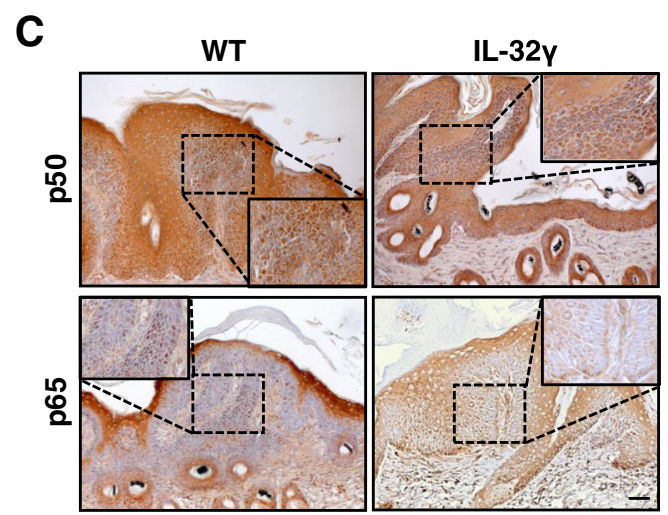

D

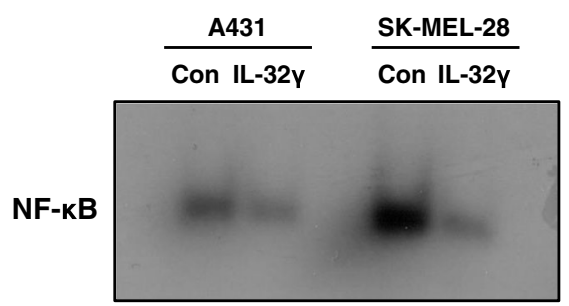

Fig. $5 \mathrm{IL}-32 \gamma$ decreases NF-KB activity in tumor tissues and skin CSCS. a and $\mathbf{b}$ Expression of phosphorylated IKKa/ $\beta$ in cytosol extracts and nuclear translocation of p50 and p65 in the nuclear extracts of DMBA/TPA-induced skin tissues or A431 and SK-Mel-28 CSCs were determined by western blotting. c Expression of p50 and p65 in DMBATPA-induced skin tissues or A431 and SK-Mel-28 CSCs were analyzed by immunohistochemistry. Scale bar, $10 \mu \mathrm{m} . n=4$. d DNA-binding activity of NF-KB was determined by EMSA in nuclear extracts of A431 and SK-Mel-28 CSCS

effect on skin CSC formation both in the control and IL-32 $\gamma$-overexpressing CSCs (Fig. 6c). However, the extent of the inhibition was more significant in IL-32 $\gamma$-overexpressing CSCs (Fig. 6c). Furthermore, we investigated whether NF- $\mathrm{kB}$ signaling was responsible for the expression of ITGAV and TIMP-1 in skin CSCs. The expression levels of ITGAV and TIMP-1 were also decreased in BAY-treated skin CSCs compared to controls (Fig. 6d). Moreover, IL-32y-overexpressing CSCs with BAY treatment reduced ITGAV and TIMP-1 expression more significantly than IL-32 $\gamma$-overexpressing CSCs (Fig. 6d). The expression levels of CD44 and CD133 were also more significantly reduced in BAY treated

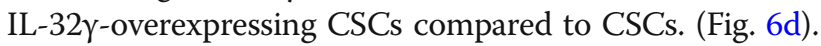
These data indicate that the inhibition of NF- $\mathrm{kB}$ was implicated in IL-32 $\gamma$-induced inhibition of skin carcinogenesis by suppression of ITGAV-mediated TIMP-1 dependent stemness and local inflammation.

\section{IL-32, ITGAV, and p65 expression in skin tumor tissues of patients}

In this study, the expression of IL-32 $\gamma$ resulted in reduced skin tumor development by downregulating ITGAV and TIMP-1 expression through the regulation of NF- $\mathrm{KB}$ signaling in IL-32 $\gamma$ mice. We analyzed the expressions levels of IL-32 $\gamma$, nuclear p65 and ITGAV in patient skin tumor tissues at different stages by immunohistochemical staining analysis. IL-32 expression was reduced in late stage skin tumor tissues (Fig. $7 \mathrm{a}$ and b). However, the expression of nuclear translocation of p65 and ITGAV were increased in the late stage skin tumors compared to normal tissues (Fig. $7 \mathrm{a}$ and $\mathrm{b}$ ).

\section{Discussion}

In this study, we found that IL-32 $\gamma$ mice showed an inhibitory effect on carcinogen-induced skin tumor development in comparison with WT mice. This observation extended our previous study, showing anti-tumor effects of IL-32 in melanoma, colon and prostate tumors [10, 47]. However, in the present study we demonstrated that the inhibitory effect of IL-32 $\gamma$ on skin cancer development was associated with preventive effects of IL-32 $\gamma$ on cancer stemness and inflammation.

IL-32, a novel cytokine, is associated with inflammation and cancer development [9]. IL-32 showed a pro-inflammatory effect in various diseases such as arthritis, Crohn's disease, and inflammatory bowel disease [9]. It has been reported that IL-32 $\alpha, \beta$, and $\gamma$ mice showed reduced colon cancer development compared to WT mice due to the inhibition of inflammation, cell cycle arrest or apoptosis in a carcinogen-induced or xenograft model $[11,13]$. It has also been reported that 


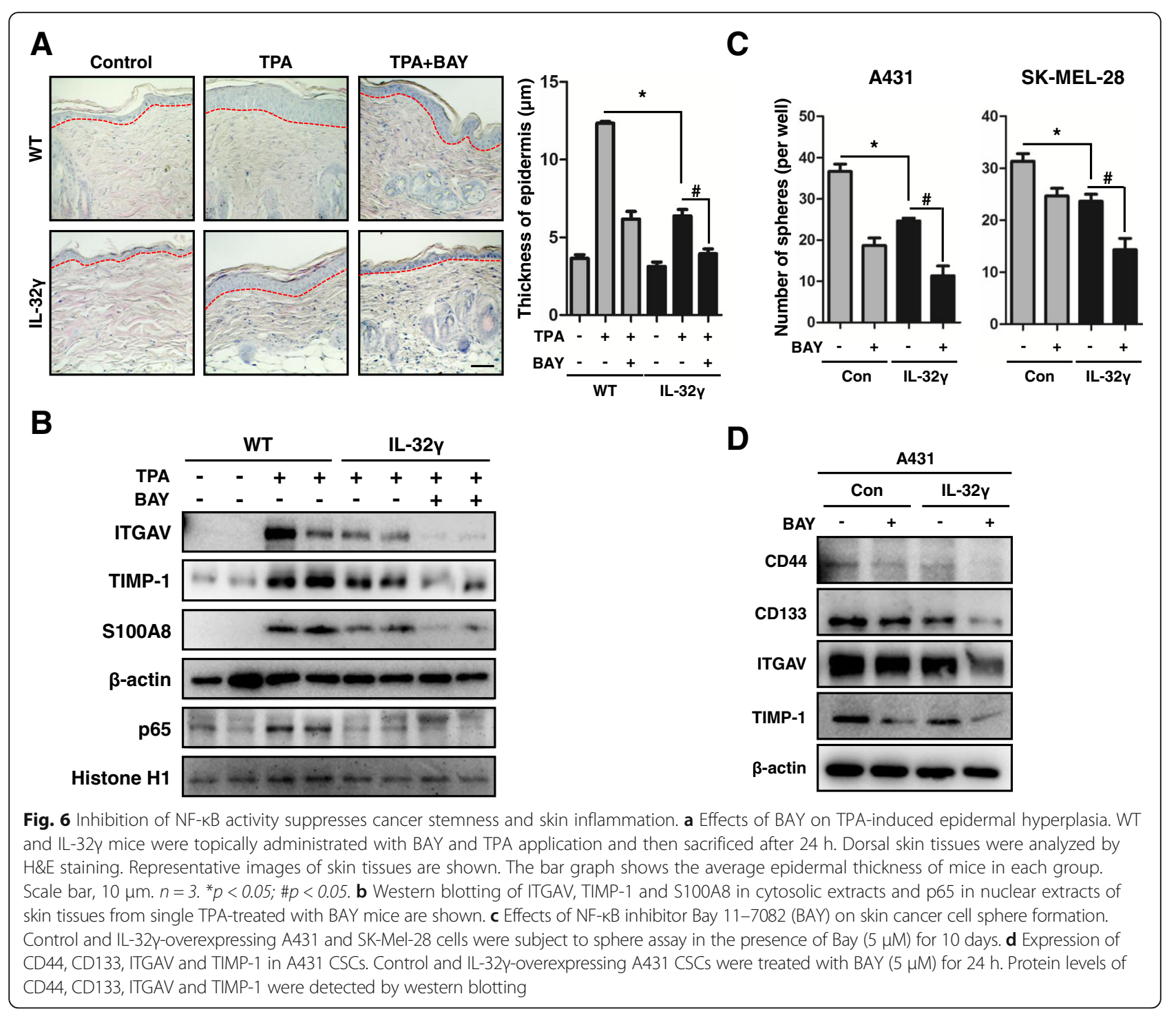

colon and prostate tumor developments were reduced in IL-32 $\beta$ mice [12]. However, the role of IL-32 $\gamma$ and the underlying mechanisms in skin cancer development has not yet been reported. In this study, we showed that IL-32 $\gamma$ inhibited skin cancer development by suppressing cancer stemness and inflammation. Unlike previous studies, the present data showed that IL-32 $\gamma$ did not directly inhibit skin cancer cell growth; however, IL-32 $\gamma$ suppressed cancer sphere formation and expression of CSC markers. Chemotherapy resistance is one of the CSC features that are related to cancer recurrence [56]. We also found that IL-32 $\gamma$ diminished chemotherapy resistance of skin cancer cells. In addition, IL-32 $\gamma$ mice had reduced CSC marker protein expression. CSCs have been identified in many tumors, including skin, breast, colon, and prostate cancer, and are known to be involved in tumor development and metastasis [60-63]. The expression of stem cell transcription factors, such as Sox2,
Nanog, and Oct4, contributed to tumorigenesis [64]. In our study, IL-32 $\gamma$ suppressed skin cancer sphere formation and the transcriptions of stem cell markers. These findings implied that the reducing effect of IL-32 $\gamma$ on cancer stemness was significant for inhibiting the effect of IL-32 $\gamma$ on skin tumor development.

In chronic inflammation, cytokines, chemokines, and tumor infiltrating inflammatory cells may promote tumor development by favoring the tumor microenvironment [21]. Pro-inflammatory cytokines, such as TNF- $\alpha$, IL-1 $\beta$, and IL-6, contribute to the induction of tumor development by enhancing cancer stemness [51, 65]. The pro-inflammatory mediator $\mathrm{PGE}_{2}$ promoted CSC expansion [66]. CSCs also elevated secretion of IL-6, RANTES and MCP-1, all of which promoted inflammation, attracted inflammatory cell infiltration and contributed to cancer progression $[67,68]$. The production of various inflammatory mediators, such as IL-1 $\beta$, IL-6, TNF- $\alpha$, 


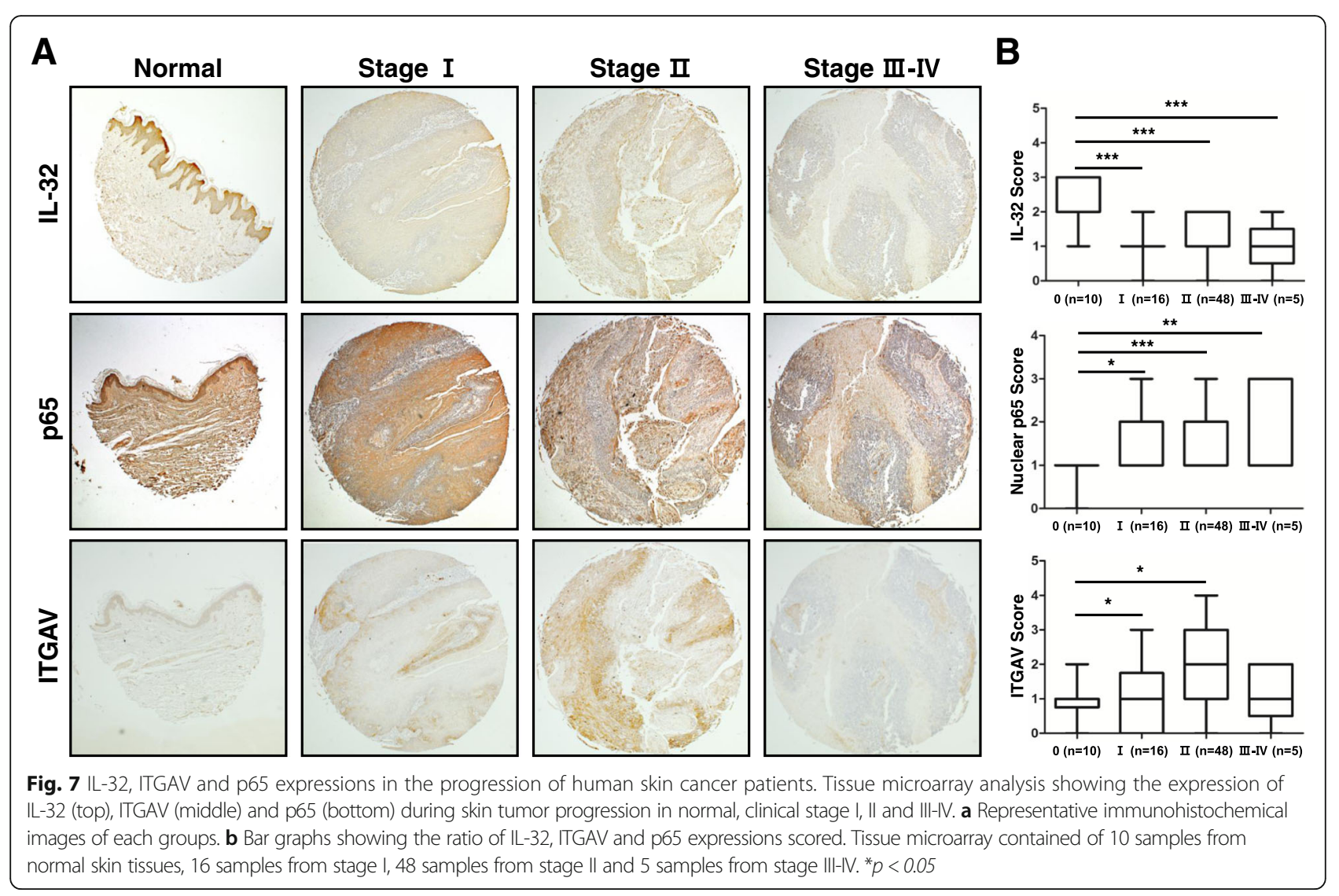

CXCL1, CXCL2, S100A8, S100A9, and $\mathrm{PGE}_{2}$, were reduced in skin tissues from DMBA/TPA-treated IL-32 $\gamma$ mice in comparison to WT mice. We also observed that IL-32 $\gamma$ reduced the recruitment of inflammatory cells, Ly6G+ granulocytes, CD11b+ monocytes/phagocytes and F4/80+ macrophages, which were associated with the production of $\mathrm{PGE}_{2}$, in skin tissues of DMBA/TPA-treated IL-32 $\gamma$ mice. However, the anti-inflammatory Th2/M2 cytokines IL-4 and IL-13 were not increased in DMBA/ TPA-induced skin tissues from IL-32 $\gamma$ mice. IL-4 and IL-13 were key players for activating tumor-associated macrophages and myeloid-derived suppressor cells that promoted tumor development [69]. In addition, IL-4 and IL-13 could increase CSC formation [70, 71]. Protein kinase $\mathrm{c}(\mathrm{PKC})$ is an initial molecular target of tumor-promoting agent TPA. IL-32 isoforms have been associated with PKC. IL-32 $\alpha$ interacts with PKC $\varepsilon$ to phosphorylate STAT3 and increased IL-6 expression in TPA-activated THP-1 cells [72]. IL-32 $\beta$ upregulated IL-10 expression by mediating $\mathrm{C} / \mathrm{EBP} \alpha$ phosphorylation (Serine 21) by PKC $\delta$ in TPA-activated U937 cells [73]. IL-32 $\theta$ suppressed CCL5 expression by interacting with PKC $\delta$ and phosphorylates STAT3 (Serine 727) in TPA-activated THP-1 cells [74]. These results implicated that IL-32y may interact with PKC isoforms and suppress inflammatory responses as an intracellular molecule. The receptor for IL-32 is still unknown; however, previous study showed that IL-32 binds to FAK, Paxillin, $\alpha \mathrm{V} \beta 3$ and $\alpha \mathrm{V} \beta 6$ integrins [75]. These studies showed that IL-32 $\gamma$ may interact with cytoplasmic membrane molecules to suppress inflammatory responses. Moreover, TPA-induced hyperplasia and inflammation as well as inflammatory cell infiltration were prevented in IL-32 $\gamma$ mice. We also found that tissues from skin tumor patients showed lower levels of IL-32 compared to healthy controls. Thus, our results demonstrated that IL-32 $\gamma$ inhibited skin carcinogenesis by the downregulation of cancer stemness through a reduced inflammatory microenvironment.

In GWAS analysis, we found that ITGAV and TIMP-1 were significantly associated with IL-32 $\gamma$-inhibited skin tumor development. ITGAV was involved in cancer progression and was expressed in many cancer types [76-78]. In mouse skin, ITGAV cooperated with p53 to transiently promote initial skin cancer development, but ultimately resulted in decreased tumor growth [33]. ITGAV knockout mice promoted skin cancer development and ITGAV expression was positively associated with cancer cell stemness and tumorigenesis in prostate and bladder cancer [34-37]. Integrin $\alpha \mathrm{V} \beta 3$ increased and maintained macrophage-induced inflammatory responses [79]. ITGAV also played critical roles in the 
inflammatory process of a number of diseases such as cancer, atherosclerosis, or rheumatoid arthritis [8082]. These facts correlated with our results revealing that IL-32 $\gamma$ suppressed cancer stemness through the inhibition of ITGAV and TIMP-1 in A431 and SK-Mel-28 skin cancer cells. Additionally, knockdown of ITGAV suppressed cancer stemness with decreased expression of cancer stem cell markers. Furthermore, expression of ITGAV was downregulated in DMBA/ TPA-induced skin tissues of IL-32 $\gamma$ mice. Tissue microarray data showed that ITGAV expression was elevated in skin cancer tissues from patients. These data indicated that the downregulation of the anti-stemness and anti-inflammatory effects of ITGAV could be associated with the reducing effect of IL-32 $\gamma$ on skin carcinogenesis. TIMP-1 is a glycoprotein and plays a role in extracellular matrix composition, wound healing, and pregnancy by regulating matrix metalloproteinases. Previous studies revealed that TIMP-1 inhibited a disintegrin and metalloprotease (ADAM)-10 activity, which regulates cancer stem-like cells and tumor growth through activation of Notch signaling in colon cancer [83, 84]. However, TIMP-1 was involved in the development of various cancer, such as melanoma, colon, and acute myeloid leukemia, through exerting an inflammatory network in the tumor microenvironment [39, 40, 85]. Melanoma cells overexpressing TIMP-1 had increased anchorage-independent growth and in vivo cancer progression $[40,86]$. Increased serum level of TIMP-1 was correlated with an unfavorable prognosis in patient with advanced stage melanoma [87]. In this study, we found that IL-32 $\gamma$ inhibited cancer sphere formation and its effect was associated with the downregulation of TIMP-1 expression in skin cancer cells. We also found that inhibition of TIMP-1 showed reduced cancer sphere formation and expression of CSC markers. The expression of TIMP-1 was also reduced in DMBA/TPA-induced skin tissues of IL-32 $\gamma$ mice. These data indicated that anti-inflammatory and anti-stemness effects by down-regulation of TIMP-1 could contribute to the

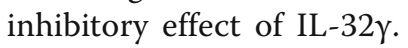

NF- $\mathrm{KB}$ has been known to act as an important transcription factor for inflammation and tumor development. In CSCs, NF- $\mathrm{kB}$ is the key player for driving self-renewal and regulating stem cell-related genes [51]. We found that cancer cell sphere formation was reduced accompanied by decreased nuclear translocation of p50 and p65 in IL-32 $\gamma$-overexpressing CSCs. In addition, inactivation of $\mathrm{NF}-\mathrm{KB}$ signaling was found in DMBA-TPA-induced skin tissues from IL-32 $\gamma$ mice. These results implicated that IL-32 $\gamma$ may directly inhibit enzyme activity of IKB kinase (IKK), which was necessary for IkB ubiquitination. Supporting our results, according to a previous study from our lab, acetylation of p65 and expression p300 were inhibited in IL-32 $\gamma$-overexpressing colon cancer cells and tumor tissues [10]. The combination of IL-32 $\gamma$ and NF-kB inhibitor, BAY, synergistically reduced TPA-induced epidermal hyperplasia, inflammation, and skin cancer sphere formation by further suppressing ITGAV and TIMP-1. Supporting our results, TPA-induced epidermal hyperplasia and inflammatory responses were attenuated in epidermal p65 knockout mice [43]. In addition, NF- $\kappa B$ inhibition suppressed breast CSC formation [88]. Moreover, NF- $\mathrm{kB}$ inhibitor treatment reduced the expression of CSC marker CD133 [89]. A previous study revealed that knockdown of TIMP-1 suppressed cell proliferation and cancer development by the inhibition of NF- $\kappa B$ signaling in breast cancer [49]. TIMP-1overexpressing melanoma showed increased CSC formation [40]. It has been implicated that TIMP-1 inhibition may suppress cancer stemness via inactivation of NF- $\mathrm{kB}$. In hepatocellular carcinoma, the integrin $\alpha \mathrm{V} \beta 3$-NF- $\mathrm{kB}-\mathrm{HIF}-1 \alpha$ pathway contributed to promoting a CSC phenotype [90]. It is also noteworthy that inhibition of ITGAV reduced prostate and bladder cancer stemness and these results may be related with integrin-mediated NF-kB signaling [91]. These findings suggested that the inactivation of NF- $\mathrm{kB}$ could contribute to IL-32 $\gamma$-induced tumor growth inhibition through blockade of skin inflammation and cancer cell sphere formation with the downregulation of ITGAV and TIMP-1.

\section{Conclusions}

This study demonstrated the inhibitory effect of IL-32 $\gamma$ on skin tumor development by the downregulation of ITGAV and TIMP-1 via the NF- $\mathrm{BB}$ signaling. Thus, IL-32 $\gamma$ could be a useful therapeutic molecule for skin cancer.

\section{Additional files}

\begin{abstract}
Additional file 1: Figure S1. IL-32 related disease network. Gene (IL-32)-disease network was analyzed based on the GWAS/OMIM/ DEG records $\left(p<10^{-6}\right)$. (TIF $\left.754 \mathrm{~kb}\right)$
\end{abstract}

Additional file 2: Figure S2. Gene network analysis. A and B, The gene map of IL-32 is shown based on known functional association networks. (TIF $517 \mathrm{~kb}$ )

Additional file 3: Table S1. List and sequences of $\mathrm{QPCR}$ primers for mRNA expression. (TIF 98 kb)

Additional file 4: Figure S3. Effect of IL-32 $\gamma$ on tumor development. DMBA/TPA-induced skin tissues from WT and IL-32 $\gamma$ mice were lysed and analyzed by western blotting for PCNA, CDK4, cyclin D1, MMP-2, MMP-9, COX-2, iNOS, p-JNK, JNK, p-ERK, ERK, p-p38, p38, p-STAT3 and STAT3. $\beta-$ actin was used as a loading control. (TIF $206 \mathrm{~kb}$ )

Additional file 5: Figure S4. Effect of IL-32 $\gamma$ on cell proliferation. HaCaT, A431 and SK-Mel-28 cells were seeded on 96 -well plates $\left(1 \times 10^{3}\right.$ cells per 
well). Cells were transfected with control or IL-32y vector for $24 \mathrm{~h}$. Cell viability was determined by MTT assay at various time points. (TIF $129 \mathrm{~kb}$ )

Additional file 6: Figure S5. Inhibition of NF-KB activity suppressed TPA-induced skin inflammation. WT and IL-32y mice were administrated with BAY and TPA application and then sacrificed after $24 \mathrm{~h}$. A, Real-time PCR analysis of different inflammatory mediators, TNF-a, IL-1 $\beta$ and IL-10, on mRNA isolated from skin tissue extracts. B, Real-time PCR analysis of mRNA expression of inflammatory cell markers, Ly6G, CD11b and F4/80. $n=3 .{ }^{*} p<0.05 ; \# p<0.05$. (TIF $\left.146 \mathrm{~kb}\right)$

\section{Abbreviations}

CSC: Cancer stem cell; DMBA: 7,12-Dimethylbenz[a]anthracene; IL: Interleukin; ITGAV: Integrin aV; NF-KB: Nuclear transcription factor-KB; TIMP-1: Tissue inhibitor of metalloproteinase-1; TPA: 12-O-Tetradecanoylphorbol-13-acetate

\section{Acknowledgements}

Not applicable.

\section{Funding}

This work was supported by the National Research Foundation of Korea (NRF) grant funded by the Korea government (MSIP) (No. MRC,2017R1A5A2015541) and the basic program (2018R1A2B2001225) of the National Research Foundation of Korea (NRF).

\section{Availability of data and materials}

The data and materials of this study are available from the corresponding authors for reasonable requests.

\section{Authors' contributions}

YSL conducted most of the experiments, performed data analysis, generated most of the experimental mice and was the primary writer of the manuscript. CHL, JTB, KTN., DBM, OKH, JSC, THK, HOJ, YSJ, DYH, and SBH provided advice throughout the project. DYY and JTH supervised the entire project and had a major role in experimental design, data interpretation, and writing the manuscript. All authors read and approved the final manuscript.

\section{Ethics approval and consent to participate}

The experimental protocols were carried out according to the guidelines for animal experiments of the Institutional Animal Care and Use Committee (IACUC) of Laboratory Animal Research Center at Chungbuk National University, Korea (CBNUA-1146-18-01).

\section{Consent for publication}

Not applicable.

\section{Competing interests}

The authors declare that they have no competing interests.

\section{Publisher's Note}

Springer Nature remains neutral with regard to jurisdictional claims in published maps and institutional affiliations.

\section{Author details \\ ${ }^{1}$ College of Pharmacy and Medical Research Center, Chungbuk Nationa University, Osongsaengmyeong 1-ro, Osong-eup, Heungdeok-gu, Cheongju, Chungbuk 28160, Republic of Korea. ${ }^{2}$ Hanbul Co, Ltd. R\&D center, 634 Eon Ju-Ro, Gangnam-gu, Seoul, Republic of Korea. ${ }^{3}$ Department of Biomaterial Science, Pusan National University, Miryang, Kyungnam 50463, Republic of Korea. ${ }^{4}$ Department of Bioscience and Biotechnology, Bio/Molecular Informatics Center, Konkuk University, Gwangjin-gu, Seoul 05029, Republic of Korea.}

\section{Received: 28 August 2018 Accepted: 22 October 2018}

\section{Published online: 28 November 2018}

\section{References}

1. Heinhuis B, Plantinga TS, Semango G, Küsters B, Netea MG, Dinarello CA Smit JWA, Netea-Maier RT, Joosten LAB. Alternatively spliced isoforms of IL-
32 differentially influence cell death pathways in cancer cell lines. Carcinogenesis. 2016;37(2):197-205.

2. Kim S-H, Han S-Y, Azam T, Yoon D-Y, Dinarello CA. Interleukin-32: a cytokine and inducer of TNFa. Immunity. 2005;22(1):131-42.

3. Kempuraj D, Conti P, Vasiadi M, Alysandratos K-D, Tagen M, Kalogeromitros D, Kourelis T, Gregoriou S, Makris M, Staurianeas NG, et al. IL-32 is increased along with tryptase in lesional psoriatic skin and is up-regulated by substance $P$ in human mast cells. Eur J Dermatol. 2010; 20(6):865-7.

4. Shioya M, Nishida A, Yagi Y, Ogawa A, Tsujikawa T, Kim-Mitsuyama S, Takayanagi A, Shimizu N, Fujiyama Y, Andoh A. Epithelial overexpression of interleukin-32a in inflammatory bowel disease. Clin Exp Immunol. 2007;149(3):480-6.

5. Dinarello CA, Kim SH. IL-32, a novel cytokine with a possible role in disease. Ann Rheum Dis. 2006:65(suppl 3):iii61.

6. Joosten $L A B$, Heinhuis $B$, Netea MG, Dinarello $C A$. Novel insights into the biology of interleukin-32. Cell Mol Life Sci. 2013;70(20):3883-92

7. Khawar MB, Abbasi MH, Sheikh N. IL-32: a novel pluripotent inflammatory interleukin, towards gastric inflammation, gastric Cancer, and chronic rhino sinusitis. Mediat Inflamm. 2016;2016:8413768.

8. Conti $P$, Youinou P, Theoharides TC. Modulation of autoimmunity by the latest interleukins (with special emphasis on IL-32). Autoimmun Rev. 2007; 6(3):131-7.

9. Hong JT, Son DJ, Lee CK, Yoon D-Y, Lee DH, Park MH. Interleukin 32, inflammation and cancer. Pharmacol Ther. 2017:174:127-37.

10. Oh JH, Cho MC, Kim JH, Lee SY, Kim HJ, Park ES, Ban JO, Kang JW, Lee DH, Shim $J H$, et al. IL-32 $\gamma$ inhibits cancer cell growth through inactivation of NFKB and STAT3 signals. Oncogene. 2011;30:3345.

11. Yun H-M, Park K-R, Kim E-C, Han SB, Yoon DY, Hong JT. IL-32a suppresses colorectal cancer development via TNFR1-mediated death signaling. Oncotarget. 2015;6(11):9061-72.

12. Yun HM, Oh JH, Shim JH, Ban JO, Park KR, Kim JH, Lee DH, Kang JW, Park $\mathrm{YH}, \mathrm{Yu} \mathrm{D}$, et al. Antitumor activity of IL-32 $\beta$ through the activation of lymphocytes, and the inactivation of NF-KB and STAT3 signals. Cell Death Dis. 2013:4:e640.

13. Bak Y, Kwon T, Bak IS, Hong J, Yu DY, Yoon DY. IL-32theta inhibits stemness and epithelial-mesenchymal transition of cancer stem cells via the STAT3 pathway in colon cancer. Oncotarget. 2016:7(6):7307-17.

14. Chen J, Wang S, Su J, Chu G, You H, Chen Z, Sun H, Chen B, Zhou M. Interleukin-32alpha inactivates JAK2/STAT3 signaling and reverses interleukin-6-induced epithelial-mesenchymal transition, invasion, and metastasis in pancreatic cancer cells. Onco Targets Ther. 2016;9: 4225-37.

15. Nicholl MB, Chen X, Qin C, Bai Q, Zhu Z, Davis MR, Fang Y. IL-32alpha has differential effects on proliferation and apoptosis of human melanoma cell lines. J Surg Oncol. 2016;113(4):364-9.

16. Lee J, Kim KE, Cheon S, Song JH, Houh Y, Kim TS, Gil M, Lee KJ, Kim S, Kim $D$, et al. Interleukin-32a induces migration of human melanoma cells through downregulation of E-cadherin. Oncotarget. 2016;7(40):65825-36.

17. Tsai CY, Wang CS, Tsai MM, Chi HC, Cheng WL, Tseng YH, Chen CY, Lin CD, Wu Jl, Wang LH, et al. Interleukin-32 increases human gastric cancer cell invasion associated with tumor progression and metastasis. Clin Cancer Res an official journal of the American Association for Cancer Research. 2014. 20(9):2276-88

18. Choi D-K, Li ZJ, Chang I-K, Yeo M-K, Kim J-M, Sohn K-C, Im M, Seo Y-J, Lee J$\mathrm{H}$, Kim C-D, et al. Clinicopathological roles of S100A8 and S100A9 in cutaneous squamous cell carcinoma in vivo and in vitro. Arch Dermatol Res. 2014;306(5):489-96.

19. Lomas A, Leonardi-Bee J, Bath-Hextall F. A systematic review of worldwide incidence of nonmelanoma skin cancer. Br J Dermatol. 2012; 166(5):1069-80

20. Rogers HW, Weinstock MA, Feldman SR, Coldiron BM. Incidence estimate of nonmelanoma skin Cancer (keratinocyte carcinomas) in the U.S. population, 2012. JAMA Dermatol. 2015:151(10):1081-6.

21. Tang L, Wang K. Chronic Inflammation in Skin Malignancies. J Mol Signal. 2016;11:2

22. Lu H, Ouyang W, Huang C. Inflammation, a key event in Cance development. Mol Cancer Res. 2006:4(4):221-33.

23. Landskron G, De la Fuente M, Thuwajit $P$, Thuwajit C, Hermoso MA. Chronic inflammation and cytokines in the tumor microenvironment. J Immunol Res. 2014;2014:149185. 
24. Li Y, Wang L, Pappan L, Galliher-Beckley A, Shi J. IL-1 $1 \beta$ promotes stemness and invasiveness of colon cancer cells through Zeb1 activation. Mol Cancer. 2012;11(1):87.

25. Chin AR, Wang SE. Cytokines driving breast cancer stemness. Mol Cell Endocrinol. 2014;382(1):598-602.

26. Plaks V, Kong N, Werb Z. The Cancer stem cell niche: how essential is the niche in regulating Stemness of tumor cells? Cell Stem Cell. 2015;16(3):225-38.

27. Reya T, Morrison SJ, Clarke MF, Weissman IL. Stem cells, cancer, and cancer stem cells. Nature. 2001;414:105.

28. Boumahdi S, Driessens G, Lapouge G, Rorive S, Nassar D, Le Mercier M, Delatte B, Caauwe A, Lenglez S, Nkusi E, et al. SOX2 controls tumour initiation and cancer stem-cell functions in squamous-cell carcinoma. Nature. 2014;511:246

29. Lapouge G, Beck B, Nassar D, Dubois C, Dekoninck S, Blanpain C. Skin squamous cell carcinoma propagating cells increase with tumour progression and invasiveness. EMBO J. 2012:31(24):4563-75.

30. Malanchi I, Peinado H, Kassen D, Hussenet T, Metzger D, Chambon P, Huber M, Hohl D, Cano A, Birchmeier W, et al. Cutaneous cancer stem cell maintenance is dependent on $\beta$-catenin signalling. Nature. 2008;452:650

31. Siegle JM, Basin A, Sastre-Perona A, Yonekubo Y, Brown J, Sennett R, Rendl M, Tsirigos A, Carucci JA, Schober M. SOX2 is a cancer-specific regulator of tumor initiating potential in cutaneous squamous cell carcinoma. Nat Commun. 2014:5:4511.

32. Palla AR, Piazzolla D, Alcazar N, Cañamero M, Graña O, Gómez-López G, Dominguez O, Dueñas M, Paramio JM, Serrano M. The pluripotency factor NANOG promotes the formation of squamous cell carcinomas. Sci Rep. 2015;5:10205.

33. Savar A, Acin S, Gonzalez CL, El-Sawy T, Mejia O, Li Z, Esmaeli B, LacyHulbert A, El-Naggar AK, McCarty JH, et al. Loss of epithelial p53 and [alpha]v integrin cooperate through Akt to induce squamous cell carcinoma yet prevent remodeling of the tumor microenvironment. Oncogene. 2015 34(4):516-24.

34. McCarty JH, Barry M, Crowley D, Bronson RT, Lacy-Hulbert A, Hynes RO. Genetic ablation of av Integrins in epithelial cells of the eyelid skin and conjunctiva leads to squamous cell carcinoma. Am J Pathol. 2008;172(6):1740-7.

35. van der Horst $G$, van den Hoogen $C$, Buijs JT, Cheung $H$, Bloys $H$, Pelger RCM, Lorenzon G, Heckmann B, Feyen J, Pujuguet P, et al. Targeting of avIntegrins in stem/progenitor cells and supportive microenvironment impairs bone metastasis in human prostate Cancer. Neoplasia. 2011;13(6):516-IN519.

36. van der Horst G, Bos L, van der Mark M, Cheung H, Heckmann B, ClémentLacroix P, Lorenzon G, Pelger RCM, Bevers RFM, van der Pluijm G. Targeting of alpha- $V$ Integrins reduces malignancy of bladder carcinoma. PLoS One. 2014;9(9):e108464

37. van den Hoogen $C$, van der Horst $G$, Cheung H, Buijs JT, Pelger RCM, van der Pluijm G. Integrin av expression is required for the Acquisition of a Metastatic Stem/progenitor cell phenotype in human prostate Cancer. Am J Pathol. 2011:179(5):2559-68.

38. Wang J, Zhang B, Wu H, Cai J, Sui X, Wang Y, Li H, Qiu Y, Wang T, Chen Z, et al. CD51 correlates with the TGF-beta pathway and is a functional marker for colorectal cancer stem cells. Oncogene. 2017;36(10):1351-63.

39. Brew K, Nagase $\mathrm{H}$. The tissue inhibitors of metalloproteinases (TIMPs): an ancient family with structural and functional diversity. Biochim Biophys Acta. 2010;1803(1):55-71.

40. Ricca TI, Liang G, Suenaga AP, Han SW, Jones PA, Jasiulionis MG. Tissue inhibitor of metalloproteinase 1 expression associated with gene demethylation confers anoikis resistance in early phases of melanocyte malignant transformation. Transl Oncol. 2009;2(4):329-40.

41. Toricelli M, Melo FH, Peres GB, Silva DC, Jasiulionis MG. Timp1 interacts with beta-1 integrin and CD63 along melanoma genesis and confers anoikis resistance by activating $\mathrm{PI} 3-\mathrm{K}$ signaling pathway independently of Akt phosphorylation. Mol Cancer. 2013;12:22.

42. Park S-A, Kim M-J, Park S-Y, Kim J-S, Lim W, Nam J-S, Yhong Sheen Y. TIMP-1 mediates TGF- $\beta$-dependent crosstalk between hepatic stellate and cancer cells via FAK signaling. Sci Rep. 2015;5:16492.

43. Kim C, Pasparakis M. Epidermal p65/NF-kB signalling is essential for skin carcinogenesis. EMBO Mol Med. 2014;6(7):970-83.

44. Huang S, Ullrich SE, Bar-Eli M. Regulation of tumor growth and metastasis by Interleukin-10: the melanoma experience. J Interf Cytokine Res. 1999; 19(7):697-703.

45. Oft M. IL-10: master switch from tumor-promoting inflammation to antitumor immunity. Cancer Immunol Res. 2014;2(3):194-9.
46. Schottelius AJ, Mayo MW, Sartor RB, Baldwin AS Jr. Interleukin-10 signaling blocks inhibitor of kappaB kinase activity and nuclear factor kappaB DNA binding. J Biol Chem. 1999;274(45):31868-74.

47. Yun HM, Oh JH, Shim JH, Ban JO, Park KR, Kim JH, Lee DH, Kang JW, Park $\mathrm{YH}, \mathrm{Yu} \mathrm{D}$, et al. Antitumor activity of IL-32[beta] through the activation of lymphocytes, and the inactivation of NF-[kappa]B and STAT3 signals. Cell Death Dis. 2013;4:e640.

48. Xia Y, Yeddula N, Leblanc M, Ke E, Zhang Y, Oldfield E, Shaw RJ, Verma IM. Reduced cell proliferation by IKK2 depletion in a mouse lung-cancer model. Nat Cell Biol. 2012;14(3):257-65

49. Cheng G, Fan X, Hao M, Wang J, Zhou X, Sun X. Higher levels of TIMP-1 expression are associated with a poor prognosis in triple-negative breast cancer. Mol Cancer. 2016;15:30.

50. Chen J-S, Hsu Y-M, Chen C-C, Chen L-L, Lee C-C, Huang T-S. Secreted heat shock protein 90a induces colorectal Cancer cell invasion through CD91/ LRP-1 and NF-KB-mediated integrin a(V) expression. J Biol Chem. 2010; 285(33):25458-66.

51. Rinkenbaugh AL, Baldwin AS. The NF-kB pathway and Cancer stem cells. Cells. 2016;5(2):16.

52. Abel EL, Angel JM, Kiguchi K, DiGiovanni J. Multi-stage chemical carcinogenesis in mouse skin: fundamentals and applications. Nat Protoc. 2009;4(9):1350-62

53. Macias E, Rao D, Digiovanni J. Role of stat3 in skin carcinogenesis: insights gained from relevant mouse models. J Skin Cancer. 2013;2013:684050.

54. Rundhaug JE, Fischer SM. Molecular mechanisms of mouse skin tumor promotion. Cancers. 2010;2(2):436-82.

55. Bao B, Ahmad A, Azmi AS, Ali S, Sarkar FH. Cancer Stem Cells (CSCs) and Mechanisms of Their Regulation: Implications for Cancer Therapy. Curr Protoc Pharmacol / editorial board, SJ Enna (editor-in-chief) [et al]. 2013;0 14:Unit-14.25.

56. Abdullah LN, Chow EK-H. Mechanisms of chemoresistance in cancer stem cells. Clin Transl Med. 2013;2:3-3.

57. Dragu DL, Necula LG, Bleotu C, Diaconu CC, Chivu-Economescu M. Therapies targeting cancer stem cells: current trends and future challenges. World J Stem Cells. 2015;7(9):1185-201.

58. Hoesel B, Schmid JA. The complexity of NF-kB signaling in inflammation and cancer. Mol Cancer. 2013;12:86.

59. Budunova IV, Perez P, Vaden VR, Spiegelman VS, Slaga TJ, Jorcano JL. Increased expression of p50-NF-kB and constitutive activation of NF-kB transcription factors during mouse skin carcinogenesis. Oncogene. 1999;18:7423.

60. Kreso A, Dick John E. Evolution of the Cancer Stem Cell Model. Cell Stem Cell. 2014;14(3):275-91.

61. Moltzahn F, Thalmann GN. Cancer stem cells in prostate cancer. Transl Androl Urol. 2013:2(3):242-53.

62. Colmont CS, Harding KG, Piguet V, Patel GK. Human skin cancer stem cells: a tale of mice and men. Exp Dermatol. 2012;21(8):576-80.

63. Chang JC. Cancer stem cells: role in tumor growth, recurrence, metastasis, and treatment resistance. Medicine. 2016;95(1 Suppl 1):S20-5.

64. Liu A, Yu X, Liu S. Pluripotency transcription factors and cancer stem cells: small genes make a big difference. Chin J Cancer. 2013;32(9):483-7.

65. Korkaya H, Liu S, Wicha MS. Regulation of Cancer stem cells by cytokine networks: attacking cancers inflammatory roots. Clin Cancer Res. 2011; 17(19):6125-9.

66. Wang D, Fu L, Sun H, Guo L, DuBois RN. Prostaglandin E(2) Promotes Colorectal Cancer Stem Cell Expansion and Metastasis in Mice. Gastroenterology. 2015;149(7):1884-1895.e1884.

67. Levina V, Marrangoni AM, DeMarco R, Gorelik E, Lokshin AE. Drug-selected human lung Cancer stem cells: cytokine network, Tumorigenic and Metastatic Properties. PLOS ONE. 2008;3(8):e3077.

68. Shigdar S, Li Y, Bhattacharya S, O'Connor M, Pu C, Lin J, Wang T, Xiang D, Kong L, Wei MQ, et al. Inflammation and cancer stem cells. Cancer Lett. 2014;345(2):271-8.

69. Suzuki A, Leland P, Joshi BH, Puri RK. Targeting of IL-4 and IL-13 receptors for cancer therapy. Cytokine. 2015;75(1):79-88.

70. Cao H, Zhang J, Liu H, Wan L, Zhang H, Huang Q, Xu E, Lai M. IL-13/STAT6 signaling plays a critical role in the epithelial-mesenchymal transition of colorectal cancer cells. Oncotarget. 2016;7(38):61183-98.

71. Nappo G, Handle F, Santer FR, McNeill RV, Seed RI, Collins AT, Morrone G, Culig Z, Maitland NJ, Erb HHH. The immunosuppressive cytokine interleukin4 increases the clonogenic potential of prostate stem-like cells by activation of STAT6 signalling. Oncogenesis. 2017;6:e342. 
72. Kang J-W, Park YS, Lee DH, Kim JH, Kim MS, Bak Y, Hong J, Yoon D-Y. Intracellular interaction of interleukin (IL)-32a with protein kinase C (PKC ) and STAT3 protein augments IL-6 production in THP-1 Promonocytic cells. J Biol Chem. 2012;287(42):35556-64.

73. Kang J-W, Park YS, Kim MS, Lee DH, Bak Y, Ham SY, Park SH, Hong JT, Yoon D-Y. Interleukin (IL)-32 $\beta$-mediated CCAAT/enhancer-binding protein a (C/ $\mathrm{EBPa}$ ) phosphorylation by protein kinase $\mathrm{C} \delta$ (PKC $\delta$ ) abrogates the inhibitory effect of C/EBPa on IL-10 production. J Biol Chem. 2013;288(33):23650-8.

74. Bak Y, Kang J-W, Kim MS, Park YS, Kwon T, Kim S, Hong J, Yoon D-Y. IL-32E downregulates CCL5 expression through its interaction with PKC $\delta$ and STAT3. Cell Signal. 2014;26(12):3007-15.

75. Heinhuis B, Koenders MI, van den Berg WB, Netea MG, Dinarello CA, Joosten LAB. Interleukin 32 (IL-32) contains a typical a-helix bundle structure that resembles focal adhesion targeting region of focal adhesion Kinase-1. J Biol Chem. 2012;287(8):5733-43.

76. Bai SY, Xu N, Chen C, Song YL, Hu J, Bai CX. Integrin alphavbeta5 as a biomarker for the assessment of non-small cell lung cancer metastasis and overall survival. Clin Respir J. 2015;9(4):457-67.

77. Bandyopadhyay A, Raghavan S. Defining the role of integrin av $\beta 6$ in cancer. Curr Drug Targets. 2009;10(7):645-52.

78. Weis SM, Cheresh DA. av Integrins in angiogenesis and Cancer. Cold Spring Harb Perspect Med. 2011;1(1):a006478.

79. Antonov AS, Antonova GN, Munn DH, Mivechi N, Lucas R, Catravas JD, Verin AD. aV $\beta 3$ integrin regulates macrophage inflammatory responses via PI3 kinase/Akt-dependent NF-kB activation. J Cell Physiol. 2011;226(2):469-76.

80. Nam EJ, Sa KH, You DW, Cho JH, Seo JS, Han SW, Park JY, Kim SI, Kyung HS, Kim IS, et al. Up-regulated transforming growth factor $\beta$-inducible gene h3 in rheumatoid arthritis mediates adhesion and migration of synoviocytes through av $\beta 3$ integrin: regulation by cytokines. Arthritis \& Rheumatism. 2006;54(9):2734-44.

81. Lee B-H, Bae J-S, Park R-W, Kim J-E, Park J-Y, Kim I-S. ßig-h3 triggers signaling pathways mediating adhesion and migration of vascular smooth muscle cells through avß5 integrin. Exp Mol Med. 2006;38:153.

82. Waisberg J, De Souza Viana L, RJA J, SRM S, MVA D, Margeotto FB, De Souza CS, Matos D. Overexpression of the ITGAV gene is associated with progression and spread of colorectal Cancer. Anticancer Res. 2014;34(10): 5599-607.

83. Atapattu L, Saha N, Chheang C, Eissman MF, Xu K, Vail ME, Hii L, Llerena C, Liu Z, Horvay K, et al. An activated form of ADAM10 is tumor selective and regulates cancer stem-like cells and tumor growth. J Exp Med. 2016;213(9): $1741-57$.

84. Amour A, Knight CG, Webster A, Slocombe PM, Stephens PE, Knäuper $V$, Docherty AJP, Murphy G. The in vitro activity of ADAM-10 is inhibited by TIMP-1 and TIMP-3. FEBS Lett. 2000;473(3):275-9.

85. Forte D, Salvestrini V, Corradi G, Rossi L, Catani L, Lemoli RM, Cavo M, Curti A. The tissue inhibitor of metalloproteinases-1 (TIMP-1) promotes survival and migration of acute myeloid leukemia cells through CD63/PI3K/Akt/p21 signaling. Oncotarget. 2017;8(2):2261-74.

86. Toricelli M, Melo FHM, Hunger A, Zanatta D, Strauss BE, Jasiulionis MG. Timp1 promotes cell survival by activating the PDK1 signaling pathway in melanoma. Cancers. 2017;9(4):37.

87. Zurac S, Neagu M, Constantin C, Cioplea M, Nedelcu R, Bastian A, Popp C, Nichita $L$, Andrei $R$, Tebeica $T$, et al. Variations in the expression of TIMP1, TIMP2 and TIMP3 in cutaneous melanoma with regression and their possible function as prognostic predictors. Oncol Lett. 2016;11(5):3354-60

88. Choi HS, Kim D-A, Chung H, Park IH, Kim BH, Oh E-S, Kang D-H. Screening of breast cancer stem cell inhibitors using a protein kinase inhibitor library. Cancer Cell Int. 2017;17:25.

89. Park EK, Lee JC, Park JW, Bang SY, Yi SA, Kim BK, Park JH, Kwon SH, You JS, Nam SW, et al. Transcriptional repression of cancer stem cell marker CD133 by tumor suppressor p53. Cell Death Dis. 2015;6:e1964.

90. Cao L, Fan X, Jing W, Liang Y, Chen R, Liu Y, Zhu M, Jia R, Wang H, Zhang X, et al. Osteopontin promotes a cancer stem cell-like phenotype in hepatocellular carcinoma cells via an integrin-NF-KB-HIF-1a pathway. Oncotarget. 2015;6(9):6627-40.

91. Guo W, Giancotti FG. Integrin signalling during tumour progression. Nat Rev Mol Cell Biol. 2004;5:816.

\section{Ready to submit your research? Choose BMC and benefit from:}

- fast, convenient online submission

- thorough peer review by experienced researchers in your field

- rapid publication on acceptance

- support for research data, including large and complex data types

- gold Open Access which fosters wider collaboration and increased citations

- maximum visibility for your research: over $100 \mathrm{M}$ website views per year

At BMC, research is always in progress.

Learn more biomedcentral.com/submissions 